SUSTAINABLE FORESTRY

COLLECTION 81-82, 2020
ODRŽIVO ŠUMARSTVO

ZBORNIK RADOVA 81-82, 2020

UDK 581.4:582.632.1=111

UDK $630 * 811: 582.632 .1=111$

Original scientific paper

\title{
CORYLUS L., ITS DIVERSITY, GEOGRAPHICAL DISTRIBUTION AND MORPHO-ANATOMICAL CHARACTERISTICS WITH SPECIAL REFERENCE TO THE SYSTEMATIC CLASSIFICATION AND PHYLOGENICS OF TURKISH HAZEL (CORYLUS COLURNA L.)
}

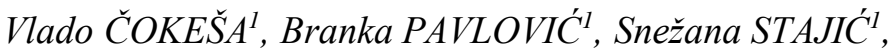 \\ Zoran PODUŠKA ${ }^{1}$, Đorđe JOVIĆ ${ }^{1}$
}

\begin{abstract}
Botanists have not yet reached an agreement regarding the number of species and lower taxa within the Corylus L. genus (hazel). According to different literature sources worldwide, 14, 16,18, or 20 species have been described within the genus. There are many synonyms in the scientific literature for the same species, which creates additional confusion in determining the total number of species within the genus. According to the WCSP (World Checklist of Selected Plant Families), (http://apps.kew.org/wcsp/synonomy.do?name_id=47827), 16 species have been recognized worldwide. According to this valid classification based on morpho-anatomical characteristics, all hazels are divided into two sections, and each section into two subsections. The paper presents the main differences between these groups and subgroups, as well as their distribution in the world. Special attention is given to the range of distribution, morpho-anatomical characteristics, systematic classification, and relatedness of Corylus colurna L. to other species.
\end{abstract}

Keywords: Genus Corylus L. - classification and distribution of species, Corylus colurna L. - morpho-anatomical characteristics and phylogeny.

${ }^{1}$ Mr Vlado Čokeša, MSc Branka Pavlović, dr Snežana Stajić, dr Zoran Poduška, dr Đorđe Jović, Institute of Forestry, Belgrade, 3 Kneza Višeslava, Serbia 


\section{ROD CORYLUS L., DIVERZITET, GEOGRAFSKA SPECIJACIJA I MORFO-ANATOMSKE KARAKTERISTIKE SA POSEBNIM OSVRTOM NA SISTEMATSKO MESTO I FILOGENIJU MEČJE LESKE (CORYLUS COLURNA L.)}

Izvod: U pogledu broja vrsta i nižih taksona, u okviru roda Corylus L. (leske), među botaničarima ne postoji saglasnost. Na osnovu različitih literaturnih izvora u okviru roda, u svetu je opisano 14, 16, 18, odnosno 20 vrsta. U naučnoj literaturi za iste vrste postoji mnogo sinonima, što stvara dodatnu zabunu u definisanju ukupnog broja vrsta u okviru roda. Prema WCSP listi (World Checklist of Selected Plant Families), (http://apps.kew.org/wcsp/synonomy.do?name_id=47827), u svetu je danas priznato 16 vrsta. Prema ovoj važećoj klasifikaciji, na osnovu morfo-anatomskih karakteristika, sve leske su podeljene u 2 sekcije i u okviru svake sekcije, 2 podsekcije. U radu su date osnovne razlike između ovih grupa i podgrupa, kao i njihovo rasprostranjenje u svetu. Poseban osvrt je dat na rasprostranjenje, morfo-anatomskih karakteristika, sistematsko mesto i srodničke veze sa drugim vrstama vrste Corylus colurna $L$.

Ključne reči: Rod Corylus L. - klasifikacija i rasprostranjenje vrsta, Corylus colurna L. - morfo-anatomske karakteristike i filogenija.

\section{INTRODUCTION}

Corylus L. (hazel) is a genus of deciduous trees and large shrubs that grow, in the temperate zone of the northern hemisphere. Some authors classify it in the birch family, Betulaceae, (Chen et al., 1999; Rushforth, 1999; Huxley, 1992), though some place the hazels (along with hornbeams and related species) into a distinct family, Corylaceae: Tribus Coryleae Meissn. 1842. Gen.: 846; Carpineae Döll. 1845. Zur Erkl. Laubkn. Ament; Podfam. Corylaeae Eichl. 1876. Syllab.:19., (Flora of Serbia II, Stevanović, 2012; Bean et al., 1976; Erdogan et al., 2002). There is no agreement among botanists on the number of species of the Corylus L. genus. According to the first group of authors, this genus has 14 species, the second and third groups state16, or 18 respectively, while the fourth group of authors states that this genus numbers as many as 20 taxa at the species level. A plethora of synonyms given to each species further increases the discrepancy in the number of species within this genus.

Moreover, in some cases, subspecies and varieties are described as species. To resolve all doubts, the whole genus is classified according to morpho-anatomical characteristics into sections and subsections. Besides the basic name taken from WCSP (World Checklist of Selected Plant Families), (http://apps.kew.org/wcsp/synynomy.do?name_id=47827), the synonyms for all species are listed. Where there are subspecies and varieties, their names are provided. 


\section{RESEARCH MATERIAL, METHOD AND AIM}

The paper deals with the taxonomy of Corylus L. (hazel), i.e., provides the systematization of all species and lower taxonomic units within this genus. Therefore, the paper aims to group the accepted species within the genus systematically on the basis of their morpho-anatomical characteristics. The division into groups and subgroups (sections and subsections) was made on the basis of their habitus (whether it is a tall tree with one shoot or a lower shrub with several shoots) and the visual appearance of the fruit dome (involucrum leaves). Accordingly, all the accepted species are grouped as follows:

I. - Shrub with several stems, shoots up to $12 \mathrm{~m}$ high. Fruit (hazelnut) surrounded by soft, leafy involucrum:

Ia. - Involucrum short, approximately the same length as the fruit (hazelnut) - (6 accepted species);

Ib. - Involucrum long, twice as long as the fruit (hazelnut) or even longer, forming a "beak" - (4 accepted species).

II. - Tree with one stem, 20-35 $\mathrm{m}$ in height. Fruit (hazelnut) surrounded by a rigid, prickly involucrum:

IIa. - Involucrum moderately prickly and with glandular hairs - (5 accepted species);

IIb. - Involucrum with dense spines, resembling a chestnut bur - (1 accepted species).

All taxa within the above classification are given synonyms and their geographical distribution. Special attention is paid to the phylogeny of Corylus colurna L., i.e., its relationships with other species from its subsection and their ranges. Based on the collected available literature data, lower category taxa are listed for each species if they are described.

\section{RESULTS}

\subsection{Systematics and taxonomy of Corylus $L$.}

\section{Fam. Corylaceae}

Tribus Coryleae Meissn. 1842. Gen.: 846; Carpineae Döll. 1845. Zur Erkl. Laubkn. Ament; Podfam. Corylaeae Eichl. 1876. Syllab.:19.

According to Flora of Serbia II (Stevanović, (ed.) 2012), these are deciduous trees or shrubs distributed exclusively in the temperate zone of the northern hemisphere.

Leaves - simple, alternate, generally serrated.

Flowers - unisexual, small, anemophilous. Male flowers - individually arranged in loose hanging catkins, with 3 to 12 or more anthers, grown on cover scales. Each flower has two bracteoles united in a bract, without a flower sheath. Female flowers - dichasia grouped in small catkins or special inflorescences in the form of buds, two in a dichasium, each with one bract and two bracteoles. The flower sheath is small, 
irregularly lobed, and more or less fused with the pistil. The ovary is unilocular or bilocular, with one ovule. There are two stigmas.

The fruit is a syncarpous nut regularly with a sheath. The pericarp is more or less woody.

The family includes the genera Carpinus, Ostrya, Corylus, and Ostryopsis.

\section{Rod: Corylus L. - hazels}

1737. Gen. Pl.ed. 1:293, n0 730; 1754. ed. 5:433, n0 953.

Name: derives from the greek word "kerys" meaning helmet, which refers to the green shell that encloses the fruit.

According to Flora of Serbia II (Stevanović, (ed.) 2012), it is a deciduous shrub, less often a tree.

$\underline{\text { Shoots }}$-slender and flexible.

Buds - oval to round, often slightly flattened, with several scales. The stipules fall off early.

Leaves - simple, alternating, mostly symmetrical, large, with double-serrated margins.

Male flowers - in hanging, cylindrical catkins that appear during the summer, preceding flowering, 2 to 4 on a common stalk. In the spring, during flowering, they elongate and become loose.

Female flowers - in twos, in small bud-like inflorescences from which reddish stigmas protrude in the spring during flowering.

Fruit - syncarpous nut (hazelnut), enclosed in a short or long tubular shell, composed of two leaves, which is open in the upper part and more or less serrated.

According to various sources, the genus includes 14-18 (20) species distributed in Europe, Asia, and North America. However, according to the WCSP, a total of 16 species have been officially accepted. The genus center is in East and Southeast Asia.

The shape and structure of the shell, as well as the habitus (whether it is a tree or a shrub with shoots) are important in species delimination, (Rushforth, 1999). Species can also be determined on the basis of pollen, under magnification (600 times), by characteristic exospores with three noticeable pores (Hubert, 1874). There is no agreement among botanists on the number of species that belong to the Corylus L genus., because some botanist consider certain species to be subspecies and vice versa. Double-naming is common and creates additional problems, since the plethora of synonyms magnifies the number of species. The determined species in East Asia are highly disputable. WCSP and Flora of China differ in the taxa that are accepted as species. Within this region, only those species that are on the "The Plant list" (a Working list of all plant species - version 1) and the list of scientific names and synonyms accepted by the Royal Botanic Garden - WCSP, are given in the list of species, (Rushforth, 1999; Wu, et al., 1999; Flora of China 4; Flora of North America 3). In accordance with the above methodology, the species are grouped as follows: 
I- Shrub with several stems, shoots up to $12 \mathrm{~m}$ high. Fruit (hazelnut) surrounded by soft, leafy involucrum:

Ia - Involucrum short, approximately the same length as the fruit (hazelnut)

- Corylus americana Walter - American hazel

Synonyms:

Corylus americana var. altior Farw.;

Corylus americana var. calyculata (Dippel) H.J.P.Winkl.;

Corylus americana $\mathrm{f}$. calyculata (Dippel) Schelle;

Corylus americana var. indehiscens Palmer \& Steyerm.;

Corylus americana f. missouriensis (A.DC.) Fernald;

Corylus calyculata Dippel;

Corylus humilis Willd.

Literature: Govaerts, R. (2003).

- Corylus avellana L. - common hazel

Synonyms:

Corylus sylvestris Salisb.

Accepted Infraspecifics:

Corylus avellana var. avellana $\mathrm{L}$.

Corylus avellana var. pontica (K.Koch) H.J.P.Winkl.,

Synonyms: Corylus imeretica Kem.-Nath.

Literature: Dimopoulos et al., (2013).

- Corylus yunnanensis (Franch.) A.Camus - Yunnan hazel, Literature: Wu, et al. (1999). Flora of China 4:

○ Corylus wulingensis Q.X.Liu \& C.M.Zhang - Asian hazel, Literature: Govaerts, R. (2003).

- Corylus heterophylla Fisch. ex Trautv. - Asian hazel

Accepted Infraspecifics:

Corylus heterophylla var. heterophylla,

Synonyms:

Corylus hasibani Siebold

Corylus heterophylla var. shenyangensis L.Zhao \& D.Chen

Corylus mongolica K.Koch

Corylus tetraphylla Ledeb.

Corylus thunbergii K.Koch

Corylus heterophylla var. sutchuenensis Franch.

Synonyms:

Corylus kweichowensis $\mathrm{Hu}$

Corylus kweichowensis var. brevipes W.J.Liang

Corylus kweichowensis var. sutchuenensis (Franch.) C.C.Yang

Corylus sutchuenensis (Franch.) Nakai

Literature: Govaerts, R. (2003).

- Corylus potaninii Bobrov - Asian hazel

Literature: Govaerts, R. (2003). 
Ib - Involucrum long, twice as long as the fruit (hazelnut) or even longer, forming a "beak"

○ Corylus cornuta Marshall - beaked hazel

Accepted Infraspecifics:

Corylus cornuta subsp. californica (A.DC.) A.E.Murray

Synonyms:

Corylus californica (A.DC.) A.Heller

Corylus cornuta var. californica (A.DC.) Sharp.

Corylus cornuta var. glandulosa B.Boivin

Corylus cornuta f. glandulosa (B.Boivin) T.C.Brayshaw

Corylus rostrata var. californica A.DC.

Corylus rostrata var. tracyi Jeps.

Corylus cornuta subsp. cornuta

Synonyms:

Corylus cornuta Du Roi ex Steud.

Corylus cornuta f. inermis Fernald

Corylus cornuta var. megaphylla Vict. \& J.Rousseau

Corylus mexicana K.Koch

Corylus rostrata Aiton

Literature: Herkert et al., (2002).

- Corylus maxima Mill.- the Filbert

Synonyms:

Corylus arborescens G.Gaertn., B.Mey. \& Scherb.

Corylus balcana P.D.Sell

Corylus balcana f. atropurpurea P.D.Sell

Corylus intermedia Fingerh.

Corylus sativa Poit. \& Turpin

Corylus tubulosa Willd.

Literature: Dimopoulos, P. \& al. (2016).

- Corylus colchica Albov - Colchican Filbert

Literature: Govaerts, R. (2003).

- Corylus sieboldiana Blume - Asian beaked hazel

Accepted Infraspecifics:

Corylus sieboldiana var. mandshurica

Synonyms:

Corylus brevituba Kom.

Corylus mandshurica Maxim.

Corylus mandshurica f. brevituba (Kom.) Kitag.

Corylus mandshurica f. glandulosa S.L.Tung

Corylus sieboldiana var. sieboldiana

Synonyms:

Corylus brevirostris (C.K.Schneid.) Miyabe

Corylus hallaisanensis Nakai

Corylus sieboldiana var. hallaisanensis (Nakai) M.Kim

Literature: Govaerts, R. (2003). 
II - Tree with one stem, 20-35 m high. Fruit (hazelnut) surrounded by a rigid, prickly involucrum,

IIa - Involucrum moderately prickly and with glandular hairs

- Corylus colurna L. - Turkish hazel

Synonyms:

Corylus abchasica Kem.-Nath.

Corylus arborescens Münchh.

Corylus bizantina Desf.

Corylus cervorum Petrov

Corylus eggrissiensis Kem.-Nath

Corylus kachetuca Kem.-Nath.

Literature: Govaerts, R. (2003).

- Corylus wangii $\mathrm{Hu}-$ Wang's hazel

Literature: Govaerts, R. (2003).

- Corylus fargesii (Franch.) C.K.Schneid. - Farges' hazel

Literature: Govaerts, R. (2003).

- Corylus chinensis Franch. - Chinese hazel

Synonyms:

Corylus papyracea Hickel

Literature: Govaerts, R. (2003).

- Corylus jacquemontii Decne. - Jacquemont's hazel

Synonyms:

Corylus lacera Wall.

Corylus tiliacea Decne.

Literature: Govaerts, R. (2003).

IIb - Involucrum with dense spines, resembling a chestnut burr

○ Corylus ferox Wall. - Himalayan hazel (Himalayas, Tibet and southwest China).

Accepted Infraspecifics:

Corylus ferox var. ferox

Corylus ferox var. tibetica (Batalin) Franch.

Synonyms:

Corylus tibetica Batalin

Literature: Govaerts, R. (2003).

The oldest confirmed species of hazel is Corylus johnsonii Pigg, Manchester $\&$ Wehr, found as a fossil in Ypresian rocks (Lower Eocene 47.8 -56.0 million years ago) in Ferry County (Washington) ( https://treesforlife.org.uk/into-the-forest/treesplants-animals/trees/hazel/hazel-mythology - and-folklore/). This was a period of global warming when forests reached the poles and the dominance of Dicotyledonae.

There are several hybrids. Crossbreeding can occur between different species of this genus, e.g. Corylus $\times$ colurnoides C.K.Schneid. (C. avellana $\times$ C. colurna), sin. Corylus $x$ intermedia Loid. 
In horticulture, the following cultivars are grown: C. avellana "Kontorta" because of the crooked and knotty stem and branches; $C$. avellana "Pendula" with hanging "weeping" branches and C. maxima "Purpurea, because of its purple leaves.

Due to their flexibility, branches are used for wattle-and-daub building and agricultural fencing. Due to the increased coppice vigour, the branches regenerate quickly after cutting the shoots. Hazel is used in land reclamation to bind the soil and in windbreaks. The fruit of all hazels is edible. Common hazel, C. avellana is mostly grown for this purpose. The fruit of other species is also used, but apart from the common hazel, the Filbert (Huxley, 1992) is the only species with commercial importance. Corylus colurna is used as the stock for grafting cultivated varieties.

\subsection{Distribution of taxa within the Corylus $L$ genus.}

\section{$\underline{\text { North America }}$}

The following taxa are widespread in North America:

1. Corylus americana Walter, Fl. Carol. 236. 1788. - American hazel.

Distribution: Canada to N. Central \& E. U.S.A. (Alabama, Arkansas, Connecticut, Delaware, District of Columbia, Georgia, Illinois, Indiana, Iowa, Kansas, Kentucky, Louisiana, Maine, Manitoba, Maryland, Massachusetts, Michigan, Minnesota, Mississippi, Missouri, Nebraska, New Hampshire, New Jersey, New York, North Carolina, North Dakota, Ohio, Oklahoma, Ontario, Pennsylvania, Québec, Rhode I., Saskatchewan, South Carolina, South Dakota, Tennessee, Vermont, Virginia, West Virginia, Wisconsin),

In America, it is considered a weed species in forests.

Literature: Govaerts, R. (2003).

2. Corylus cornuta Marshall, Arbust. Amer. 37. 1785. - beaked hazel.

Corylus cornuta subsp. californica (A.DC.) A.E.Murray

Distribution: British Columbia to California

\section{Corylus cornuta subsp. cornuta}

Distribution: Canada to N. \& E. U.S.A. (Alabama, Alberta, British Columbia, Colorado, Connecticut, Georgia, Idaho, Illinois, Iowa, Kentucky, Labrador, Maine, Manitoba, Maryland, Massachusetts, Michigan, Minnesota, Montana, New Brunswick, New Hampshire, New Jersey, New York, Newfoundland, North Carolina, North Dakota, Nova Scotia, Ohio, Ontario, Pennsylvania, Prince Edward I., Québec, Rhode I., Saskatchewan, South Carolina, South Dakota, Tennessee, Vermont, Virginia, Washington, West Virginia, Wisconsin, Wyoming)

Literature: Herkert et al. (2002).

3. Corylus avellana Linnaeus, Sp. Pl. 2: 998. 1753. - common hazel. It is listed in the flora of North America, but it was introduced to this continent from Europe. 
There are 14 accepted species in Asia, 9 of which are found in China (Wu, et al. (1999). Flora of China 4:):

1. Corylus yunnanensis (Franchet) A. Camus, Bull. Mus. Natl. Hist. Nat., sér. 2. 1: 438. 1929. - Yunnan hazel.

Distribution: China South-Central,

Literature: $\mathrm{Wu}$, et al. (1999). Flora of China 4:

Its habitats are thickets on mountain slopes at altitudes of 1600-3700 m.

2. Corylus wulingensis Q.X.Liu \& C.M.Zhang - Asian hazel,

Distribution: China Southeast (Hunan),

Literature: Govaerts, R. (2003).

3. Corylus heterophylla Fischer ex Trautvetter, Pl. Imag. Descr. 10. 1844. - Asian hazel.

Corylus heterophylla var. heterophylla,

Distribution: SE. Siberia, S. Russian Far East, E. Mongolia, N. \& NE. China, Korea, N. \& Central Japan (Amur, China North-Central, Chita, Japan, Khabarovsk, Korea, Manchuria, Mongolia, Primorye),

Corylus heterophylla var. sutchuenensis Franch.

Distribution: China South-Central, China Southeast (Yunnan, Sichuan, Guizhou, Hubei, Hunan)

It inhabits broadleaved forests of thickets of temperate climate, on mountain slopes, at altitudes of $400-2500 \mathrm{~m}$.

Literature: Govaerts, R. (2003).

4. Corylus potaninii Bobrov - Asian hazel.

Distribution: China South-Central

Literature: Govaerts, R. (2003).

5. Corylus sieboldiana Blume - Asian beaked hazel, Japanese hazel.

\section{Corylus sieboldiana var. mandshurica}

Distribution: SE. Siberia, China to N. \& Central Japan (Amur, Chita, Japan, Khabarovsk, Korea, Manchuria, Primorye)

Corylus sieboldiana var. sieboldiana

Distribution: S. Korea, Japan.

It inhabits forests and thickets of temperate climate, at 400-2600 $\mathrm{m}$ a.s.l.

Literature: Govaerts, R. (2003).

6. Corylus wangii Hu, Bull. Fan Mem. Inst. Biol., n.s. 8: 31. 1938. - Wang's hazel .Distribution: China South-Central (Yunnan)

It inhabits broadleaved forests in the temperate zone up to $3000 \mathrm{~m}$ above sea level. Endangered species. It is similar to Corilus jackuemontii Decaisne, from the Himalayas.

Literature: Govaerts, R. (2003).

7. Corylus fargesii C. K. Schneider, Ill. Handb. Laubholzk. 2: 896. 1912. - Farges' hazel. 
Distribution: China (China North-Central, China South-Central, China Southeast, Inner Mongolia)

It inhabits forests in mountain valleys of 800-3000 $\mathrm{m}$ above sea level.

Literature: Govaerts, R. (2003).

8. Corylus chinensis Franchet, J. Bot. (Morot). 13: 197. 1899. Rare and vulnerable species.

\section{Distribution: S. Central China}

It inhabits forests on moist mountain slopes of 1200-3500 m above sea level.

Literature: Govaerts, R. (2003).

9. Corylus ferox Wallich, P1. Asiat. Rar. 1: 77. 1830. - Himalayan hazel.

Corylus ferox var. ferox

Distribution: Central Himalayas to S. Central China (Assam, China South-Central, Eastern Himalayas, Myanmar, Nepal)

Corylus ferox var. tibetica (Batalin) Franch.

Distribution: Tibet to Central \& N. China (China North-Central, China SouthCentral, Inner Mongolia, Tibet)

It inhabits forests on mountain slopes of 1500-3800 $\mathrm{m}$ above sea level.

Literature: Govaerts, R. (2003).

10. Corylus colchica Albov 1985. - Colchican filbert

Distribution: W. Transcaucasus (Armenia and Georgia endemic)

It forms thickets on the northern edge of the forest zone. It is frost-resistant

Literature: Govaerts, R. (2003).

11. Corylus jacquemontii - Jacquemont's hazel.

Distribution: Kashmir to W. Nepal (Nepal, Western Himalayas, India)

It inhabits forests and thickets at 1800-3000 $\mathrm{m}$ above sea level.

Literature: Govaerts, R. (2003).

12. Corylus colurna Linnaeus - Turkish hazel.

Distribution in Asia: SW Asia, N. Iran to Afghanistan (Iran, Transcaucasus, Turkey, Afghanistan)

Literature: Govaerts, R. (2003).

13. Corylus maxima Mill. - the Filbert .

Distribution in Asia: SW Asia (Turkey)

Literature: Dimopoulos, P. et al., (2016).

14. Corylus avellana $\mathrm{L}$. - common hazel.

Corylus avellana var. avellana $\mathrm{L}$.

Distribution in Asia: (Transcaucasus, Turkey),

Corylus avellana var. pontica (K.Koch) H.J.P.Winkl.,

Distribution in Asia: N. Turkey, W. Transcaucasus (East Aegean Is., Transcaucasus, Turkey)

Its habitats are forests and thickets. 
Literature: Dimopoulos, et al., (2013).

\section{Europe}

The last 3 species that are found in Southeast Asia are also widespread in Europe:

1. Corylus avellana L. - common hazel.

\section{Corylus avellana var. avellana $\mathrm{L}$.}

Distribution in Europe: (Albania, Austria, Baltic States, Belarus, Belgium, Bulgaria, Central European Russia, Corsica, Czech, Denmark, East European Russia, Finland, France, Faeroe Islands, Germany, Great Britain, Greece, Hungary, Ireland, Italy, Crimea, Montenegro, the Netherlands, North European Russia, North Caucasus, North Macedonia, Northwest European Russia, Norway, Poland, Portugal, Romania, Sardinia, Serbia, Sicily, Slovakia, South European Russia, Spain, Sweden, Switzerland, Ukraine),

It is widely distributed in Europe. Its habitats are forests and thickets.

Literature: Dimopoulos, P., et al., (2013).

2. Corylus maxima Mill. - the Filbert

Distribution in Europe: SE Europe (Bulgaria, Greece, North Macedonia, Turkey-inEurope)

Literature: Dimopoulos, P. et al. (2016).

3. Corylus colurna Linnaeus - Turkish hazel, Turkish filbert

Distribution in Europe: SE. Europe, (Bosnia and Herzegovina, Albania, Bulgaria, Greece, Montenegro, North Caucasus, North Macedonia, Romania, Serbia, Turkeyin-Europe)

Literature: Govaerts, R. (2003).

\subsection{Species: Corylus colurna $\mathrm{L}$ - Turkish hazel}

C. colurna L. 1753. Sp. P1.: 999; Pančić 1874. Fl. Knež. Srbije: 627; Hayek 1924. Prodr. Fl. Penins. Balc. 1:69; C. pontica Koch 1849 in Linnaea 22:329. Turkish hazel or Turkish filbert.

According to Flora of Serbia II (Stevanović, (ed.) 2012), it is a tree up to 25 (30) $\mathrm{m}$ high and up to $75(100) \mathrm{cm}$ in diameter, with a conical to broad rounded crown. It reaches the age of over 200 years.

The bark is grayish-white to dark gray, soft, thick, corky, with regular shallow longitudinal cracks.

Shoots - annual are hairy and yellowish; biennial are corky and light gray.

Buds - egg-shaped, large, 6 to $7 \mathrm{~mm}$ long, hairy, dark-brown.

Leaves - widely oval or obovate, dark green on the upper side, pubescent along veins underside, 7 to $12 \mathrm{~cm}$ long and 5 to $10 \mathrm{~cm}$ wide, roughly double-serrated, sharply tapered towards the top. The leaf base is more or less heart-shaped. The leaf blade ends in nerves in the base near the petiole.The petiole is 2 to $5 \mathrm{~cm}$ long, noticeably 
longer than in common hazel, bare, with loose simple hairs, rarely with dense glandular hairs.

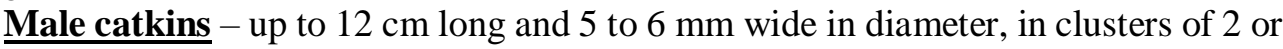
3.

Fruit - hazelnut (filbert) enclosed in a fleshy, often densely glandular-hairy sheath that is open in the upper part, narrow from the very base, elongated, hard. The long, thread-like extensions of the sheath bent on all sides greatly exceed the fruit and cover it. The fruit grows in clusters of 3 to 8 . The nut is smaller than in C. avellana, 17 to $20 \mathrm{~mm}$ long and 12 to $18 \mathrm{~mm}$ wide, widest in the middle or in the lower portion. The scar extends from the base over the lateral sides, sometimes covering half of the hazelnut. The fruit ripens in September and October, when it falls off and is collected.

Germination - underground, cotyledons remain in the sheath, the first leaves are close-fitting, alternate, undeveloped, the subsequent leaves are elongated-ovate, with coarsely and unevenly double-serrated margins.

Habitat. It grows in shady forests, at an altitude of up to $1500 \mathrm{~m}$, mostly on limestone but also on other rocks, often in canyons and gorges and on plateaus above them. It builds a number of communities of mixed composition and structure, such as: Fago-intermedio-Colurnetum B.Jov., Fagetum montanum colurnetosum B.Jov., Carpinetum orientalis serbicum colurnetosum B.Jov., Colruno-Pinetum nigrae B.Jov., Fago-Colurnetum mixtum Mišić, Querco-Colurnetum mixtum Mišić, Syringo-Colurnetum mixtum Mišić, Syringo-Aceri monspessulani-Coryletum colurnae Mišić, Syringo-Aceri intermedii-Coryletum colurnae B. Jov., etc.

General distribution. - Central and Eastern Dinarides (Bosnia and Herzegovina and Montenegro), central and eastern parts of the Balkan Peninsula (Serbia, Albania, Macedonia), northern Greece (Epirus), Bulgaria, southern Carpathians (Romania), northern parts of Asia Minor (Turkey), Caucasus (Armenia and Georgia), mountains of northern Iran to Afghanistan. It has a special place in the dendroflora of Serbia as a Tertiary relict that was widespread on the Balkan Peninsula as early as the Oligocene. It belongs to the following floral element: central-eastern DinaricBalkan-southern Carpathian-Euxin-Caucasian-northern Iranian; submerid; colmont.

Distribution in Serbia. NE: Đerdap (Čoka Njalta, Pesača, Gospođin Vir, Lepenski Vir, Boljetin, Veliki Kazan, Mali Kazan, Mali Štrbac and Veliki Štrbac), GrebenMiroč, Pek Gorge near Debeli Lug, Ribare, Vitovnica Gorge, Krepoljin, Gornjačka Gorge, Lazareva River Canyon near Zlot, Malinik, Dubašnica, between Majdanpek and Rudna, Selačka River Canyon near s. Suvodol, Svrljiški Timok Gorge, Resava Gorge, Grza Gorge, Ivanštica Gorge, Moravica Gorge, Ozren, Devica, Rtanj, Tupižnica: E: Sićevačka Gorge (Oblik, Vis, Kunovica), Jelašnica Gorge, Suva Planina, Šljivovički Vis, Vlaška Planina; Jerma Gorge; Vidlič; Greben Mountain; slopes of Stara Planina - Toplodolska River Basin; Sukovska River Gorge - Jerma, Pčinj Gorge, Kozjak, W: Tara (Vijača), Divčibare, Povlen (Kukalj) SW: Mileševka Gorge, around Tutin; C: Mali Jastrebac, Kopaonik, M: Paštrik, Kodža Balkan, Koprivnik (Peć); K: Milanovac Planina, Đonaj, Suva Planina (Novo Selo), Grmija, Drenica Planina (Klečka, Crn (Ladrović)), Čičavica (Šalce), Suk, Crnoljeva planina. Economic significance. The wood is dense, firm, and has a beautiful pink tinge. It can be processed, polished, and used for making furniture, veneers, and various 
turning items. Its can bind soil particles. It is used in shelterbelts and windbreaks. Due to the regular and beautiful crown, it is often used as an ornamental tree in avenues, parks, and gardens. Regarding its plantation forms, there rare hybrid specimens of common hazel with Turkish hazel and vice versa Corylus $\mathrm{x}$ colurnoides, which are characterized by predominantly intermediary properties.

\subsection{Phylogeny of Corylus colurna $L$.}

Turkish hazel (Corylus colurna L.) belongs to the group of relict representatives of the dendroflora of Southeast Europe. In the absence of fossils from the Miocene-Pliocene period in Europe, its relict character is indicated primarily by the habitus of the tall tree and recent relatedness to species from China and the Himalayas. Namely, Corylus colurna belongs to the section Corylus Li \& Chang 1979 and the subsection Colurnae Witcher 1999, which also includes C. Chinensis, C. Fargesii. C. wangii from China and $C$. jacquemontii from the Himalayas. Close relatedness of these 5 species is indicated by ITS sequence analyzes (Witcher \& Wen, 2001). Such disjunct distribution of related species of Holarctic deciduous dendroflora is also found in genera such as Castanea, Liquidambar, Ostrya, Platanus, Aesculus, Styrax, Sibbirea, but also in whole genera such as Quercus, Fagus, Acer, Fraxinus, Carpinus, Tilia, etc., indicating the historical unity of the arcto-tertiary geoflora.

\section{DISCUSSION}

The results of the research list a total of 16 accepted species within the genus of Corylus L. that are on the WCSP, with all the synonyms under which these species are described, as well as their lower taxonomic units (subspecies, variety and form). There are two species on the list that are not present in the flora of China: Corylus wulingensis Q.X.Liu \& C.M.Zhang and Corylus potaninii Bobrov. There is little information about them in the literature, although they are internationally recognized. On the other hand, the flora of China includes the other two species Corylus formosana Hayata (Gen. Ind. Pl. Form. 72. 1916) and Corylus sieboldiana Blume. Corylus formosana Hayata has been described in Taiwan but has not been recognozed as a species (Flora of China 4: 286-289. 1999). Corylus sieboldiana Blume is included in the WCSP but according to its description and range of distribution, it is described as Corylus mandshurica Maxim in the Flora of China. On the WCSP, Corylus mandshurica Maxim. is synonymous with Corylus sieboldiana Blume.

According to Fukarek (1956), Corylus colurna L. is an ancient Tertiary species that was widespread in the Balkans as early as the Oligocene, when beech, hornbeam, and other recent species had already been widespread here, as well as many species from some genera that have completely disappeared from this area (Pterocarya, Sequoia, Cinnamomum, Glyptostrobus and others).

Today, the range of distribution of Corylus colurna L. stretches from the western parts of the Balkan Peninsula, through Southeast Asia to the slopes of the Himalayas. The largest range of its distribution on the Balkan Peninsula is located in Serbia and Bulgaria. Corylus colurna L. was once thought to extend to western 
China as Corylus colurna var. chinensi. (Ascherson P. in Graebner P. 1908), Fukarek (1956). However, according to the WCSP, Corylus chinensis is a distinct Chinese species belonging to the same section and subsection as Corylus colurna. According to the same authors, even Corylus heterophylla (Asian hazel), which belongs to a completely different section and subsection, was identified with Corylus colurna, which was completely wrong.

Fukarek (1956) cites references of various authors who claim that Corylus byzantina Duhamel and Corylus pontica K. Koch are separate species, or that Corylus pontica is related to Corylus maxima. However, according to the current classification, Corylus byzantina is nothing but a synonym for Corylus colurna and Corylus pontica is a variety of the common $\mathrm{n}$ hazel Corylus avellana var. pontica (K.Koch) H.J.P.Winkl. with a range of distribution in N. Turkey, W. Transcaucasus (East Aegean Is., Transcaucasus, Turkey). Likewise, Corylus jacquemontii Decassne (Jacqumont hazel or Himalayan hazel) is presented as a synonym or variety of the Corylus colurna L. However, it is accepted as a distinct species according to the WCSP.

Very little is known about the variability of Corylus colurna. The variety of glandulifera DC. was described in Greece in 1906, Maire et Petitmengin (1908). This variety was also found in Herzegovina, Korica (1950).

As a relict species, it builds polydominant forest communities in Serbia, most often in the northern sides of canyons, gorges, mountain slopes, and karst plateaus.

\section{CONCLUSIONS}

The genus Corylus, according to some authors belongs to the family Betulaceae, while others classify it as a distinct family - Corylaceae.

Scientists do not agree on the number of species either. Namely, the genus has 14, 16, 18, or 20 species. For one species there are several synonyms, subspecies, and varieties, which in some cases are described as distinct species. All this creates additional confusion in the perception of the total number of species.

According to the WCSP (World Checklist of Selected Plant Families), there are officially 16 species. In this paper, all accepted species are classified into 2 groups according to habitus and anatomical-morphological characteristics of fruit domes, and $\mathrm{v}$ each group into 2 subgroups:

I Fruit (hazelnut) surrounded by soft, leafy involucrum, shrub with several stems, shoots up to $12 \mathrm{~m}$ high:

Ia Involucrum short, approximately the same length as the fruit (hazelnut)

- Corylus americana - American hazel (Eastern North America)

- Corylus avellana - common hazel (Eureope and western Asia)

- Corylus yunnanensis - Yunnan hazel (central and southern China)

- Corylus wulingensis - Asian hazel,

- Corylus heterophylla - Asian hazel,

- Corylus potaninii Bobrov - Asian hazel. 
Ib Involucrum long, twice as long as the fruit (hazelnut) or even longer, forming a "beak"

- Corylus cornuta - beaked hazel (North America)

- Corylus maxima - the Filbert (SE Europe and SW Asia)

- Corylus colchica - Colchican Filbert (Caucasus - Armenia and Georgia endemic)

- Corylus sieboldiana - Asian beaked hazel (SE Asia and Japan)

II Fruit (hazelnut) surrounded by a rigid, prickly involucrum. Tree with one stem, $\underline{20-35 \mathrm{~m} \text { in height. }}$

IIa Involucrum moderately prickly and with glandular hairs

○ Corylus colurna - Turkish hazel (southeastern Europe and southwestern Asia)

- Corylus wangii - Wang's hazel (southwestern China)

- Corylus fargesii - Farges' hazel (western China)

- Corylus chinensis - Chinese hazel (western China)

- Corylus jacquemontii - Jacquemont's hazel (Himalayas - India)

IIb Involucrum with dense spines, resembling a chestnut burr

- Corylus ferox - Himalayan hazel (Himalayas, Tibet and southwestern China).

There are 2 indigenous species on the North American continent. There are 3 species distributed on the Eurasian continent, while 10 more species are distributed in Asia alone, 8 of which are distributed in China.

Turkish hazel (Corylus colurna L.) is widespread in southeastern Europe and southwestern Asia. It belongs to the group of relict representatives of the dendroflora of Southeast Europe. Its relict character in Europe is indicated primarily by the of the tall tree habitus and recent relatedness to species from China and the Himalayas. Namely, Corylus colurna belongs to the section Corylus Li \& Chang 1979 and the subsection Colurnae Witcher 1999, which also includes C. Chinensis, C. Fargesii. $C$. wangii from China and $C$. jacquemontii from the Himalayas. The main scientific contribution of this paper lies in the comprehensive set of data collected on the genus Corylus L, systematic classification of its species based on morphoanatomical characteristics and comprehensive data regarding the representatives of this genus.

\section{REFERENCES}

Airy, Hubert (1874): "Pollen-grains in the Air". Nature. 10 (253): 355. Bibcode:1874 Natur..10..355A. doi:10.1038/010355b0. S2CID $\underline{4077214}$

Bean, William Jackson (1976): "Trees and Shrubs Hardy in the British Isles". 1. Taylor, George (8th ed.). London: J. Murray. ISBN 0719517907. OCLC 103403

Chen, Zhi - Duan; Manchester, Steven R; Sun, Hai - Ying (August 1999): "Phylogeny and evolution of the Betulaceae as inferred from DNA sequences, morphology, and paleobotany". American Journal of Botany. 86 (8):11681181. doi:10.2307/2656981. ISSN 0002-9122. JSTOR 2656981. PMID 10449397. 
Dimopoulos, P. \& al. (2016): "Vascular plants of Greece": An annotated checklist. Supplement Willdenowia 46: 301-347.

Dimopoulos, P., Raus, T., Bergmeier, E., Constantinidis, T., Iatrou, G., Kokkini, S., Strid, A., \& Tzanoudakis, D. (2013): "Vascular plants of Greece". An annotated checklist: 1-372. Botanic gardens and botanical museum Berlin-Dahlem, Berlin and Hellenic botanical society, Athens.

Erdogan, V.; Mehlenbacher, S. A. (2002): "Phylogenetic analysis of hazelnut species (Corylus, Corylacae) based on morphology and phenology". Sist. Bot. Dergisi. 9: 83-100.

Flora of North America:

http://www.efloras.org/florataxon.aspx?flora_id=1\&taxon_id=108088

Fukarek Pavle (1956): "Turkish hazel (Corylus colurna L.) and its sites in Bosnia and Herzegovina"

Govaerts, R. (2003): "World Checklist of Selected Plant Families Database in ACCESS": 1216203. The Board of Trustees of the Royal Botanic Gardens, Kew.;

Herkert, J.R. \& Ebinger, J.E. (eds.) (2002): "Endangered and Threatened Species of Illinois: status and distribution 1: 1-161". Endangered species protection board, Springfield, Illinois. https://treesforlife.org.uk/into-the-forest/trees-plants-animals/trees/hazel/hazel-mythologyand-folklore/

Huxley, A. (ed.) (1992): "New RHS Dictionary of Gardening. Macmillan” ISBN 0-33347494-5.

Korica B. (1950): "A contribution to the knowledge of the flora of Velež" (Herzegovina), Yearbook of the Biological Institute in Sarajevo Year III. Vol. 1-2. S. 10.

Li, P. C., and Cheng, S. X. (1979): "Betulaceae" in Flora Republicae Popularis Sinicae, Vol. 21, eds K.-Z. Kuang and P.-C. Li (Beijing: Science Press).

Maire R. et Petitmengin L. (1908): "Etudes des Plants Vasculaires recoltees en Grece“"(1906), Nancy (1908) S. 200

Rushforth, K. (1999): “Trees of Britain and Europe”. Collins ISBN 0-00-220013-9.

Stevanović, B. (ed.) (2012): Flora of Serbia II, Serbian Academy of Sciences and Arts, Department of Natural and Mathematical Sciences, Belgrade.

Whitcher, I. N., and Wen, J. (2001): "Phylogeny and biogeography of Corylus (Betulaceae)": inferences from ITS sequences. Syst. Bot. 26, 283-298. doi: 10.1043/0363-6445-26.2.283

Wu, Z. \& Raven, P.H. (eds.) (1999): Flora of China 4: 1-453. Missouri Botanical Garden Press, St. Louis.

WCSP: http://apps.kew.org/wcsp/synonomy.do?name_id=47827 


\section{CORYLUS L. GENUS, ITS DIVERSITY, GEOGRAPHICAL DISTRIBUTION AND MORPHO-ANATOMICAL CHARACTERISTICS WITH SPECIAL REFERENCE TO THE SYSTEMATIC CLASSIFICATION AND PHYLOGENICS OF TURKISH HAZEL (CORYLUS COLURNA L.)}

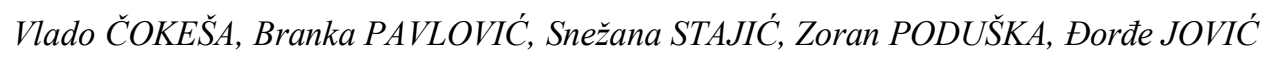

\section{Summary}

Some authors classify Corylus L. in the Betulaceae family, while according to others it belongs to the Corylaceae family. There is no agreement among botanists on the total number of species of this genus. Thus, in the literature, there are data on 14, 16, 18, or 20 taxa at the species level. The paper presents the species that are on the WCSP (World Checklist of Selected Plant Families) as officially accepted, with all their synonyms and taxa of lower ranks (subspecies, variety, form). Each species is given its range of distribution in the world. Special attention is given to Corylus colurna L. and its relatedness with other species within the section and subsection. The paper provides a clear and systematic presentation of all representatives of the genus Corylus L. and the reader can find all the most important information and resolve doubts about the representatives of this genus.

\section{ROD CORYLUS L., DIVERZITET, GEOGRAFSKA SPECIJACIJA I MORFO- ANATOMSKE KARAKTERISTIKE SA POSEBNIM OSVRTOM NA SISTEMATSKO MESTO I FILOGENIJU MEČJE LESKE (CORYLUS COLURNA L.)}

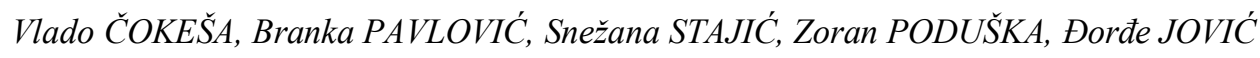

\section{Rezime}

Rod Corylus L. je prema nekim autorima svrstan u familiju Betulaceae dok je prema drugim svrstan u familiju Corylaceae. Kod botaničara ne postoji slaganje o ukupnom broju vrsta ovog roda. Tako u literaturi postoje podaci o 14, 16, 18 ili 20 taksona na nivou vrste. U radu su date vrste koje se nalaze na WCSP (World Checklist of Selected Plant Families) listi kao zvanično priznate sa svim svojim sinonimima i taksonima nižeg ranga (subspecies, varijetet, forma). Za svaku vrstu je data njena distribucija u svetu. Poseban osvrt je dat na vrstu Corylus colurna L. i njene srodničke odnose u okviru sekcije i podsekcije u kojoj se nalazi. Rad nam pruža preglednost i sistematski prikaz svih predstavnika roda Corylus L. gde čitalac moče naći sve najbitnije informacije i otkloniti nedoumice oko predstavnika ovog roda. 